\title{
Clinical and obstetric situation of pregnant women who require prehospital emergency care
}

\author{
Situação clínica e obstétrica de gestantes que solicitam o serviço médico de emergência pré-hospitalar \\ Situación clínica y obstétrica de gestantes que solicitan el servicio médico de urgencia prehospitalaria
} "Universidade Regional do Cariri. Juazeiro do Norte, Ceará, Brazil.

How to cite this article:

Freitas VCA, Quirino GS, Giesta RP, Pinheiro AKB.

Clinical and obstetric situation of pregnant women who require prehospital emergency care.

Rev Bras Enferm. 2020;73(Suppl 4):e20190058 doi: http://dx.doi.org/10.1590/0034-7167-2019-0058

\section{Corresponding author:}

Vívien Cunha Alves de Freitas

E-mail: vivien-alves@hotmail.com

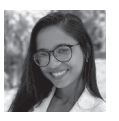

EDITOR IN CHIEF: Antonio José de Almeida Filho ASSOCIATE EDITOR: Fátima Helena Espírito Santo

Submission: 04-24-2019 Approval: 04-30-2020

\begin{abstract}
Objectives: to identify the clinical and obstetric situation of pregnant women who required emergency care, considering the adequacy of their requirement. Methods: this is a crosssectional study, developed in the headquarters of the Mobile Emergency Care Services from a state in the Brazilian Northeast, through the analysis of 558 reports of obstetric patients attended in 2016. The magnitude of the associations was expressed by odds ratio and confidence intervals, considering a 5\% significance level. Results: more than half $(50.9 \%)$ requirements for emergency care were from women who went into labor (non-expulsive), especially among third trimester pregnant women $(p<0.000)$. Most clinical and obstetric parameters were normal. Conclusions: the inadequate demands for emergency care services reflect the excessive medicalization of the gestational process and shows how important it is to discuss the physiological symptoms that involve pregnancy, so that a more egalitarian and efficient urgency service can be offered.

Descriptors: Pregnant Women; Emergencies; Emergency Medical Services; Prehospital Emergency Care; Pregnancy Complications.
\end{abstract}

\section{RESUMO}

Objetivos: identificar a situação clínica e obstétrica de gestantes que solicitam atendimento de urgência, considerando-se a pertinência da solicitação. Métodos: estudo transversal, desenvolvido na sede do Serviço de Atendimento Móvel de Urgência de um estado nordestino, por intermédio da análise de 558 relatórios de atendimentos obstétricos de 2016. A magnitude das associações foi expressa pela razão de chances e intervalo de confiança, considerando-se nível de significância de $5 \%$. Resultados: mais da metade $(50,9 \%)$ das solicitações de atendimento de urgência deu-se por queixas de trabalho de parto (sem caráter expulsivo), sobretudo entre gestantes no terceiro trimestre gestacional $(p<0,000)$. Observou-se predominância de parâmetros clínicos e obstétricos dentro da normalidade. Conclusões: a demanda não pertinente ao serviço de urgência reflete a medicalização desmedida do processo gestacional, mostrando a importância da discussão sobre sintomas fisiológicos que envolvem a gravidez, para proporcionar um serviço de urgência mais equitativo e eficiente.

Descritores: Gestantes; Emergências; Serviços Médicos de Emergência; Assistência PréHospitalar; Complicações na Gravidez.

\section{RESUMEN}

Objetivos: identificar la situación clínica y obstétrica de gestantes que solicitan atención de urgencia, considerándose la pertinencia de la solicitación. Métodos: estudio transversal, desarrollado en la sede del Servicio de Atención Móvil de Urgencia de un estado nordestino, por intermedio del análisis de 558 informes de atenciones obstétricas de 2016. La magnitud de las asociaciones ha sido expresa por la razón de oportunidades e intervalo de confianza, considerándose nivel de acepción de 5\%. Resultados: más de la mitad (50,9\%) de las solicitaciones de atención de urgencia ha se dado por quejas de trabajo de parto (sin carácter expulsivo), sobretodo entre gestantes en el tercero trimestre gestacional $(p<0,000)$. Se observó la predominancia de parámetros clínicos y obstétricos dentro de la normalidad. Conclusiones: la demanda no pertinente al servicio de urgencia refleja la medicalización desmedida del proceso gestacional, mostrando la importancia de la discusión sobre síntomas fisiológicos que envuelven la gravidez, para proporcionar un servicio de urgencia más equitativo y eficiente.

Descriptores: Gestantes; Emergencias; Servicios Médicos de Emergencia; Asistencia Prehospitalaria; Complicaciones en la gravidez. 


\section{INTRODUCTION}

During pregnancy, women are under especial health conditions, specific of this state. However, they might have clinical and/or obstetric conditions that are negative for their health or that of the fetus, being thus a part of the group of "high risk pregnancies"(1). In these situations, pregnant women must have, as a guarantee, their responsible referral to the adequate service, with easy transit between health services ${ }^{(2)}$.

Considering the possibility of health complications related to pregnancy, if risk is detected, specialized attention is required, including exams and/or evaluations in additional consultations to monitor their condition ${ }^{(3)}$. However, for the service to treat equally people who require emergency attention, prehospital services must carry out triages based on criteria to define the severity of each case ${ }^{(4)}$.

In obstetrics, triages and embracing are particularities inherent to the needs and demands of the pregnancy process. These include the investigation of common complaints in the gestational period, including headaches, nausea, vomit, and blurred vision, symptoms that can hide clinical states and require fast action. As a result, health teams must be prepared to offer qualified listening and to offer precise clinical evaluations ${ }^{(5-6)}$.

In addition, the embracing and classification of obstetric risks are guaranteed by Rede Cegonha (RC - the "Stork Network"), released in 2011 by the federal government. These actions lead to better decision-making by health workers, based on the active listening of pregnant women and associated to a clinical evaluation based on protocols and evidences ${ }^{(7)}$.

In the Brazilian context, the main prehospital public service is the Mobile Emergency Care Service (SAMU), instituted by the Ministry of Health through decree No. 2048/GM, from November 5, 2002. This service promotes, in urgency situations, transportation and adequate and safe attention for clients who are victimized by health problems, including clinical and/or obstetric ones ${ }^{(8)}$.

Despite taking into account risk classification criteria from the RC and the Manual for Embracing and Risk Classification in Obstetrics from the Ministry of Health ${ }^{(4)}$, the lack of a specific obstetric charts in the institution leads to weaknesses in the articulation of health services, showing different ways to operate in many different levels of complexity. This, in turn, leads to obstetric demands that are not in accordance to the profile of urgent $\operatorname{cases}^{(3,9)}$. Demands for emergencies are classified merely by the perception of the population about their own health situation, meaning that they are not based on the criteria of priority and severity established by the regulation centers of the service ${ }^{(4,10)}$.

Considering the specificities and the relevance of the obstetric field, this was the theme chosen for this study. In addition, health problems during pregnancy, worldwide, have been increasing. The association of demographic factors, lifestyle, and advances in modern medicine made it possible to detect them early, in time to respond. As a result, the number of cases increased, since the records/diagnostics of the problems "have been" notified ${ }^{(11)}$. Among the main worrying clinical situations during pregnancy that have been described in literature, stand out urinary infections (UI), that represent nearly $40 \%$ of these health problems ${ }^{(12-13)}$; anemia, in $27.2 \%$ of pregnancies; hypertensive syndromes, which affect from $8 \%$ to $10 \%$ of cases; and hyperemesis gravidarum, which affects from $0.3 \%$ to $3.2 \%$, depending on the country where the mother was born ${ }^{(14-15)}$.

Therefore, this research aims to identify the clinical and obstetric situation of women who require emergency mobile care services and to evaluate them with regards to the pertinence of the classification criteria proposed by Rede Cegonha and by the Manual for Embracing and Risk Classification in Obstetrics, from the Ministry of Health ${ }^{(4)}$.

This study is thought to be relevant due to the epidemiology of maternal health and fetal health problems, coupled with the importance of guaranteeing that the public services are egalitarian, fast, efficient, and capable of dealing with the health problems of the population, especially attending those who need it.

\section{OBJECTIVES}

To identify the clinical and obstetric situation of pregnant women who require attention from the SAMU, considering the adequacy of their requirement for this emergency service ${ }^{(4)}$.

\section{METHODS}

\section{Ethical aspects}

This research was approved by the Research Ethics Committee of the Universidade Federal do Ceará (PROPESQ/CEP/UFC), under legal opinion No. 2.028.066/2017. Data collection from the SAMU was carried out by the technical director of the Permanent Education Center (PEC) of the institution, after the researcher presented the proper official letter. This research respected all ethical prescriptions from resolution 466/2012, from the National Council of Health ${ }^{(16)}$.

\section{Design, period, and place of study}

This is a cross-sectional study, carried out in the headquarters of the Mobile Emergency Care Services (SAMU), in a small city in the Northeast of Brazil. The service is in a metropolitan region and attends to the entire state. Data was collected from February to July 2017, through the records (called "RAS" - Records of Attention Services) of obstetric care events that took place from January to December 2016.

\section{Sample; criteria of inclusion and exclusion}

The sample of the study included 763 records; however, in compliance with inclusion and exclusion criteria, only 558 became part of the final sample.

Eligibility criteria were: the record must have been of an obstetric incident that took place from January to December 2016. "Open" records, that is, those in which the patient was not attended by the health workers, were excluded. The reason for this were varied including situations in which the pregnant women did not wait for the SAMU and was taken to the hospital by third parties; prank calls; and calls being canceled by the person who required the service. 


\section{Study protocol}

The records, or RAS, are made when someone asks for the assistance of SAMU. They include data relative to the place of the incident, complaints from the person requesting the service, clinical and/or obstetric situation (from a primary evaluation of the victim) and has fields to describe medication prescription and scheduling, nursing progress, medical progress, and for the progress of the health worker driving the ambulance. It also includes data about the hospital to which the victim was taken. It stands out that this type of report (or record) is common to all incidents the service is asked to attend. That includes traumatic, psychiatric, obstetric, and clinical incidents, with the exception of patients with acute myocardial infarctions (AMI) and/or cerebrovascular accidents (strokes), which have their own specific records.

Once the pre-hospital urgency services were required by a call to the number 192 in all national territory, the complaints of the requiring patient are sent to the Regulating Center, which will analyze the requirement according to the severity of the situation. Health workers in an adequate ambulance go to the victim when this analysis indicates that it is the best option.

\section{Analysis of results and statistics}

Information from the RAS were transcribed into a data collection instrument developed with the objectives of this research in mind. Later, it was organized and stored in Microsoft Excel ${ }^{\oplus}$ spreadsheets.

Data was analyzed using the software IBM SPSS (version 23). Absolute and relative frequencies were calculated for qualitative variables, and the chi-square test was used to verify the association between variables. The magnitude of associations was expressed using odds ratio. For all inferential procedures, a significance level of $5 \%$ was used, meaning that $p<0.05$ was considered significant.

\section{RESULTS}

The primary evaluation of the victim, a group of initial procedures that make it possible to understand early the signs that put the life of the victim at risk, is presented in Table 1. Most pregnant women presented opened airways, with good respiratory frequency. Most were normocardic, with normal breathing and $\mathrm{O} 2$ saturation parameters. Regarding their circulation (heart rate), values up to 115 beats per minute were found to be normal, considering a progressive and physiological increase of 10 to $15 \%$ heartbeats per minute during gestation ${ }^{(17)}$.

Regarding pressure levels, most patients had normal blood pressure (BP) levels when analyzed, that is, $\mathrm{BP} \leq 139 \times 89 \mathrm{mmHg}^{(18)}$. Alarming situations, such as those indicated by a $B P \geq 140 \times 90$ and $\geq 160 \times 110 \mathrm{mmHg}$, when evaluated simultaneously, represented 125 cases, $22.5 \%$ of the obstetric occurrences attended.

To evaluate the level of consciousness, the service uses, by standard, the Glasgow Coma Scale ${ }^{(19)}$. Most patients presented a score from 13 to 15 , indicating a preserved consciousness and/or mild head injuries. The last item evaluated corresponds to body exposure, in which possible lesions can be detected through a minute evaluation of the victim. It was found that 98 patients, $7 \%(n=548)$, did not have any wounds, while $1,2 \%$ ( $n$ $=7$ ) did. Among these, some resulted from firearms and cutting weapons, in addition to bruised limbs due to traffic accidents.

Table 1 - Primary evaluation of the victim according to SAMU protocols, Fortaleza, Ceará, Brazil, January 2016

\begin{tabular}{|c|c|c|}
\hline $\begin{array}{l}\text { Variables } \\
(n=558)\end{array}$ & $\mathbf{N}$ & $\%$ \\
\hline \multicolumn{3}{|l|}{ Airways } \\
\hline Opened & 399 & 71.6 \\
\hline Obstructed & 4 & 0.7 \\
\hline Orotracheal intubation & 4 & 0.7 \\
\hline Not answered & 151 & 27 \\
\hline \multicolumn{3}{|l|}{ Respiration } \\
\hline Eupneic & 528 & 94.6 \\
\hline Tachypneic (> 20irpm) & 20 & 3.6 \\
\hline Not answered & 10 & 1.8 \\
\hline \multicolumn{3}{|l|}{ Circulation - cardiac frequency } \\
\hline Normocardiac & 450 & 80.6 \\
\hline Tachycardiac & 102 & 18.4 \\
\hline Not answered & 6 & 1 \\
\hline \multicolumn{3}{|l|}{$\mathrm{O}_{2}$ saturation } \\
\hline$\geq 95 \%$ & 499 & 89.5 \\
\hline$<95 \%$ & 16 & 2.9 \\
\hline Not answered & 43 & 7.6 \\
\hline \multicolumn{3}{|l|}{ Blood pressure levels } \\
\hline Up to $139 \times 89 \mathrm{mmHg}$ & 411 & 73.7 \\
\hline$\geq 140 \times 90$ and $<160 \times 110 \mathrm{mmHg}$ & 84 & 15 \\
\hline$\geq 160 \times 110 \mathrm{mmHg}$ & 41 & 7.4 \\
\hline Not answered & 22 & 3.9 \\
\hline \multicolumn{3}{|l|}{ Neurological - Glasgow Coma Scale } \\
\hline Mild injury (score from 13 to 15 ) & 496 & 88.9 \\
\hline Moderate injury (score from 9 to 12 ) & 6 & 1 \\
\hline Severe injury (score from 3 to 8 ) & 5 & 0.9 \\
\hline Not answered & 51 & 9.2 \\
\hline \multicolumn{3}{|l|}{ Exposure - lesions in the body } \\
\hline No & 548 & 98.2 \\
\hline Yes & 7 & 1.2 \\
\hline Not answered & 3 & 0.6 \\
\hline
\end{tabular}

Regarding age and clinical and obstetric characteristics of the patients, shown in Table 2, most women who asked for emergency care were from 18 to 35 years of age $-76.9 \%(n=423)$. Their mean age was 24, with a minimum of 12 and a maximum of 47 .

Pregnant women, in the third trimester of pregnancy, with a gestational age $\geq 28$ weeks, required attention more frequently, $77.3 \%$ $(n=282)$, than those who were in the second and third trimesters of pregnancy. Regarding their obstetric history, most had already been pregnant, $41.6 \%(n=232)$ and had never had an abortion $43.5 \%(n=243)$. Regarding their prenatal consultations, only $3.8 \%$ ( $=21)$ of the records had this information, and $83.3 \%(n=10)$ of the respondents whose data was present had had up to 6 consultations.

An expressive amount of data that is relevant for obstetric care was not in the records of the patients who required the service.

The main obstetric incident registered in 2016 by the mobile pre-hospital service was women in labor (non-expulsive), with $50.9 \%(n=284)$, followed by requirements due to birth-related discomfort or for transportation between maternities. The latter were grouped under the item "other", with $14.2 \%(n=79)$ of calls. Urgent requirements - such as abortions, $6.1 \%(n=34)$; preeclampsia, 5.9\% ( $n=33)$; and transvaginal bleeding, 5.7\% $(n=$ 
32) - were less frequent, as shown in Table 3. In addition, in $6.3 \%$ $(n=35)$ of the incidents, the reason for the call was not registered.

Table 2 - Age and clinical and obstetric features of patients who required the service, Fortaleza, Ceará, Brazil, January 2016

\begin{tabular}{|c|c|c|}
\hline $\begin{array}{l}\text { Variables } \\
(n=558)\end{array}$ & $\mathbf{N}$ & $\%$ \\
\hline \multicolumn{3}{|l|}{ Age group } \\
\hline$<18$ years old & 90 & 16.2 \\
\hline $18-35$ years old & 423 & 75.8 \\
\hline$>35$ years old & 37 & 6.6 \\
\hline Not answered & 8 & 1.4 \\
\hline \multicolumn{3}{|l|}{ Pregnancy trimester } \\
\hline First (<14 weeks) & 26 & 4.6 \\
\hline Second (from 14 to 27 weeks) & 57 & 10.2 \\
\hline Third (> 28 weeks) & 282 & 50.5 \\
\hline Not answered & 193 & 34.7 \\
\hline \multicolumn{3}{|l|}{ Number of previous pregnancies } \\
\hline One & 99 & 17.7 \\
\hline Two & 93 & 16.6 \\
\hline$\geq$ three & 139 & 25 \\
\hline Not answered & 227 & 40.7 \\
\hline \multicolumn{3}{|l|}{ Number of previous births } \\
\hline Zero & 109 & 19.6 \\
\hline From one to two & 137 & 24.5 \\
\hline$\geq$ three & 47 & 8.4 \\
\hline Not answered & 265 & 47.5 \\
\hline \multicolumn{3}{|l|}{ Number of previous abortions } \\
\hline Zero & 243 & 43.5 \\
\hline From one to two & 4 & 0.7 \\
\hline$\geq$ three & 1 & 0.3 \\
\hline Not answered & 310 & 55.5 \\
\hline \multicolumn{3}{|l|}{ Prenatal consultations } \\
\hline Yes & 21 & 3.8 \\
\hline No & 6 & 1 \\
\hline Not answered & 531 & 95.2 \\
\hline \multicolumn{3}{|c|}{ If yes, how many prenatal consultations? } \\
\hline Up to six & 10 & 1.8 \\
\hline More than six & 2 & 0.3 \\
\hline Does not apply & 6 & 1 \\
\hline Not answered & 540 & 96.9 \\
\hline
\end{tabular}

Table 3 - Obstetric incidents attended by the SAMU, Fortaleza, Ceará, Brazil, January 2016

\begin{tabular}{lcc}
\hline $\begin{array}{l}\text { Cause of the incident } \\
\text { (n= 558) }\end{array}$ & $\mathbf{N}$ & $\%$ \\
\hline Women went into labor ${ }^{1}$ (not in the expulsive stage) & 284 & 50.9 \\
Other* & 79 & 14.2 \\
Abortion & 34 & 6.1 \\
Pre-eclampsia & 33 & 5.9 \\
Transvaginal bleeding & 32 & 5.7 \\
Eclampsia & 26 & 4.7 \\
Unspecified injury & 18 & 3.2 \\
Ectopic pregnancy & 17 & 3 \\
Not registered in the records** & 35 & 6.3
\end{tabular}

Note: SAMU - Mobile Emergency Care Service; ${ }^{1}$ Not in the expulsive stage of labor, with $>5$ minutes intervals between the contractions, according to the records; *Other: pain in the lower abdomen and lumbar areas, sick feeling, nausea, vomit, among other physiological symptoms characteristic of a pregnancy; ${ }^{* *}$ The record was characterized as obstetric and the health workers attended the patient; however, they did not describe the reason for the occurrence.

The requirements to the SAMU, including the obstetric features of the patients, presented in Table 4, were divided, for clarity, in: "going into labor" and "other causes"; the latter involves all other types of incident, among which the four most common ones stand out: "others", abortion, pre-eclampsia, and transvaginal bleeding. Women in the third semester ( $\geq 28$ weeks gestation) are more likely to ask for emergency care than those in earlier semesters, since they start labor and have other conditions. This association was found to be statistically significant: $p=0.000$.

Multigravidas required the mobile prehospital care more often, especially due to labor. However, the characteristics associated with their gravidity, parity, and history of abortions did not show any statistical relation with requiring labor or other complaints that are common in the gestational period, according to Table 4.

Table 4 - Association of obstetric characteristics of women who requirements care from the SAMU, Fortaleza, Ceará, Brazil, January 2016

\begin{tabular}{|c|c|c|c|c|c|c|}
\hline & \multicolumn{2}{|c|}{$\begin{array}{c}\text { Going into } \\
\text { labor } \\
(\mathbf{n}=284)\end{array}$} & \multicolumn{2}{|c|}{$\begin{array}{c}\text { Other } \\
\text { causes } \\
(\mathbf{n}=\mathbf{2 7 4})\end{array}$} & \multirow[t]{2}{*}{$\begin{array}{c}p \\
\text { value }\end{array}$} & \multirow[t]{2}{*}{$\begin{array}{c}\text { OR } \\
\text { (IC95\%) }\end{array}$} \\
\hline & $\mathbf{N}$ & $\%$ & $\mathbf{N}$ & $\%$ & & \\
\hline Gestational age per trimester & & & & & 0.000 & $1.9(1.1-3.3)$ \\
\hline $1^{\circ}$ & 0 & 0 & 25 & 9.1 & & \\
\hline $2^{\circ}$ & 12 & 4.2 & 46 & 16.8 & & \\
\hline $3^{\circ}$ & 155 & 54.6 & 127 & 46.3 & & \\
\hline Not answered & 117 & 41.2 & 76 & 27.8 & & \\
\hline Gravidity & & & & & 0.730 & $1.1(0.7-2.1)$ \\
\hline Primigravida & 45 & 15.8 & 49 & 17.9 & & \\
\hline Multigravida & 126 & 44.4 & 88 & 32.1 & & \\
\hline Not answered & 113 & 39.8 & 137 & 50 & & \\
\hline Parity & & & & & 0.5 & $1.2(0.7-2.1)$ \\
\hline Primiparous & 49 & 17.2 & 55 & 20.1 & & \\
\hline Multiparous & 99 & 34.9 & 68 & 24.8 & & \\
\hline Not answered & 136 & 47.9 & 151 & 55.1 & & \\
\hline Previous abortions & & & & & 0.542 & $1.4(0.5-4.9)$ \\
\hline None & 121 & 42.6 & 104 & 38 & & \\
\hline One or more & 27 & 9.5 & 19 & 6.9 & & \\
\hline Not answered & 136 & 47.9 & 151 & 55.1 & & \\
\hline
\end{tabular}

Regarding their age, most pregnant women in this research were from 18 to 35 years old, with a mean of 24 . Surveys carried out in the cities of Porto Alegre/RS and Floriano/PI also show a predominance of women in this age group; respectively, they found a higher prevalence of attention for women in the age groups from 26 to 35 , and from 20 to $29^{(20-21)}$. This is seen as positive, since these women are in a period of a woman's reproductive life with better biological conditions for a pregnancy ${ }^{(22)}$.

Most pregnant women who received emergency care were in the third trimester of pregnancy ( $\geq 28$ weeks), a statistically significant association. Also, most of them were multigravidas and multiparous, which corroborates a previous research ${ }^{(23)}$, according to which $80.7 \%$ of the pregnant women attended were in the third trimester, and $38.4 \%$ of them were multiparous. A study on the expectancies and emotions of women during birth found that participants in this period of their pregnancy, generally, expect to give an easy and fast birth. Additionally, since they are closer to the end of their pregnancy, they may experience a strong desire to go to the hospital when they present any physiological pregnancy-related discomfort or sign, which they associate with labor. That can be a reflection of the medicalization of processes related to the puerperal and pregnancy cycle ${ }^{(24-25)}$. 
However, the knowledge the woman has about the period of the pregnancy they are experiencing should be considered, especially the knowledge they acquired from prenatal consultations. A research carried out in a teaching hospital, a reference for high-risk prenatal examinations in the city of Uberaba, in 2016 , showed that $58 \%$ of pregnant women reported that they did not receive guidance about the warning signs for childbirth during prenatal assistance ${ }^{(26)}$. The lack of knowledge about pregnancy reiterates the need for health education strategies - in different contexts and institutions which would involve moments for the sharing of experiences, the consolidation of knowledge, and the clarification of doubts ${ }^{(27)}$.

Blood pressure, in the pregnant women analyzed, at the moment they received care, was mostly up to $139 \times 89 \mathrm{mmHg}$, values considered normal ${ }^{(18)}$. However, it would also be ideal to identify the abrupt increase of $30 \mathrm{mmHg}$ in systolic pressure and $15 \mathrm{mmHg}$ in diastolic pressure, situations that represent hypertensive risks during gestation. It is important to be constantly vigilant with regards to the blood pressure of pregnant women, since they are more susceptible to hypertensive pathology incidents that can lead to bad outcomes for both mother and fetus ${ }^{(6-7)}$.

The main complication reported by the women was nonexpulsive childbirth, which corroborates national(28-29) and $^{(30-31)}$ international researches. However, situations in which childbirth is not expulsive and contractions take place at intervals longer than five minutes should not be given priority according to emergency care criteria, meaning that they must receive the healthcare needed in the Healthcare Center nearest to their homes ${ }^{(4)}$.

However, these centers are only opened in certain periods of the day, and primary healthcare units lack trained professionals, minimal supplies and medication for urgencies, adequate spaces to receive these women, and observation rooms with the equipment needed to offer attention to low severity/complexity emergencies, not to mention the faulty integration of Primary Healthcare services with the other services in the assistance network ${ }^{(32)}$.

The high rates of normal vital signs in pregnant women analyzed in this study corroborate the findings of an earlier research which analyzed the obstetric attention offered by SAMU in the city of Botucatu, in 2012. This research found that most patients had normal vital signs. According to the risk classification for pregnancies proposed by the Ministry of Health, $75.5 \%$ of obstetric requests that year did not justify the use of the prehospital urgency services ${ }^{(15)}$.

The high demand of people with normal clinical conditions leads to the overload in the use of mobile prehospital care services, hospital units, and maternities. These can lead to high levels of non-urgent cases, to the detriment of potentially serious cases. When the perception of the pregnant women about the attention they received from the SAMU was evaluated, with regards to the obstetric demands that should not have been attended by these professionals, it was found that most women thought the service was easy to access, fast, and that professionals were available; they asked for it as soon as they noticed health alterations ${ }^{(17)}$.

The lack of knowledge and the myth surrounding pregnancy often lead women and their relatives to become insecure and concerned. The lack of clear and objective information, even when the woman attends prenatal consultations, is one of the factors that lead them to search emergency care without actually needing it ${ }^{(9)}$. A previous study found that there is a considerable number of pregnant women who do not receive guidance in prenatal consultations on the signs and symptoms of childbirth, nor on the difference between them and the Braxton-Hicks contractions ${ }^{(33)}$.

An adequate monitoring of pregnancy allows risks and problems to be identified in a timely manner, so that complications are avoided, and damage is kept to a minimum. The percentage of adherence to the consultations prescribed by the Ministry of Health (six during pregnancy and one in puerperium) increased through the years, from $46 \%$ (2000) to $61 \%(2010)^{(23)}$.

Consequently, there is a high demand for urgency and emergency services, obstetric or not, without a real need. This can lead to the disorganization of these services, to unnecessary expenditure, and to the irrational use of resources. That also prevents equal access to the services in situations that are actual urgencies ${ }^{(9)}$. This situation may lead to a high number of users who cannot receive attention in urgency and emergency services, and need to find another way to enter the SUS, contributing for excessive transit between services ${ }^{(9,25)}$.

From this perspective, data analyzed is in accordance to the reality presented in other studies and is capable of reflecting the mistaken use of emergency care by the population, which leads to situations of stress ${ }^{(25)}$.

Finally, much important information related to pregnancy assistance is missing from the records, including data on gestational age, history of previous pregnancies, deliveries, abortions, and whether the pregnant woman went to prenatal consultations. This makes it more difficult to have an in-depth knowledge about the state of the pregnancy of these women, and to identify the risk they are under and the health vulnerabilities of this specific population.

\section{Study limitations}

The retrospective analysis of medical records and the absence of certain data that would be important to reach the goals of this study were limiting factors that diminished the size of the sample.

\section{Contributions to the fields of Nursing, Health, or Public Policy}

Knowledge about the clinical and obstetric situation, when associated with the pertinence of calls requesting emergency healthcare, allowed this study to identify the profile of pregnant women who request this type of assistance the most, and the health conditions they are in. This enables strategies aimed at diminishing the number of calls that should not be the responsibility of emergency care, and as a result, leads to a more egalitarian and efficient prehospital service. However, this study highlights the importance of strengthening educational strategies for primary healthcare, in order to transform the perspective that associates pregnancy with hospitalization and leads to the excessive medicalization of pregnancy-related physiological processes, and as a result, must be discussed.

\section{CONCLUSIONS}

This study found a high rate of requests for emergency care that were not pertinent to this type of prehospital service, according 
to the protocol of obstetric risk classification, from the Ministry of Health ${ }^{(8)}$. It was also found that, in most cases, clinical and obstetric parameters were normal. The situations, as a result, did not present the signs of severe or emergency cases that would demand attention from SAMU, especially in the case of the assistance to third-semester pregnancy, since these women mentioned physiological signs and symptoms of non-expulsive childbirths. It is essential to popularize information on the objectives and pertinence of the service for the community and for health services, in order to promote an egalitarian and effective pre-hospital attention, making it possible to diminish rates of hospitalization and of the unnecessary use of medication.

\section{FUNDING/ACKNOWLEDGEMENT}

To the CAPES/CNPq, for the contributions given to this research through a post-graduation master's degree scholarship.

\section{REFERENCES}

1. Figueiredo FSF, Borges PKO, Paris GF, Alvarez GRS, Zarpellon LD, Pelloso SM. Atención gestacional conforme inicio del prenatal: estudio epidemiológico. O Braz J Nurs. 2013;12(4):794-804. doi: 10.5935/1676-4285.20134259

2. Ministério da Saúde (BR). Portaria no 1020/GM/MS, de 29 de maio de 2013. Institui as diretrizes para a organização da Atenção à Saúde na Gestação de Alto Risco e define os critérios para a implantação e habilitação dos serviços de referência à Atenção à Saúde na Gestação de Alto Risco, incluída a Casa de Gestante, Bebê e Puérpera (CGBP), em conformidade com a Rede Cegonha [Internet]. Brasília: Ministério da Saúde, 2013[cited 2019 Jan 20]. Available from: http://bvsms.saude.gov.br/bvs/saudelegis/gm/2013/prt1020_29_05_2013.html

3. Sampaio AFS, Rocha MJF, Leal EAS. Gestação de alto risco: perfil clínico-epidemiológico das gestantes atendidas no serviço de pré-natal da maternidade pública de Rio Branco, Acre. Rev Bras Saude Mater. Infant. 2018;18(3):559-66. doi: 10.1590/1806-93042018000300007

4. Ministério da Saúde (BR). Secretaria de Atenção à Saúde. Manual de acolhimento e classificação de risco em obstetrícia [Internet]. Departamento de Ações Programáticas Estratégicas. Departamento de Atenção Hospitalar e Urgência. Brasília; 2017 [cited 2019 Jan 20$].$ Available from: http://bvsms.saude.gov.br/bvs/publicacoes/manual_acolhimento_classificacao_risco_obstetricia.pdf

5. Figueiroa MNM, Menezes MLN, Monteiro EMLM, Aquino JM, Mendes NOG, Silva PVT. Acolhimento do usuário e classificação de risco em emergência obstétrica: avaliação da operacionalização em maternidade-escola. Esc Anna Nery. 2017;21(4):e20170087. doi: 10.1590/2177-9465-ean-2017-0087

6. Lacerda IC, Moreira TMM. Características obstétricas de mulheres atendidas por pré-eclâmpsia e eclampsia. Acta Sci Health Sci. 2011;33(1):71-6. doi: 10.4025/actascihealthsci.v33i1.7711

7. Ministério da Saúde (BR). Portaria n 1.459, de 24 de junho de 2011. Institui no âmbito do Sistema Único de Saúde - SUS - a Rede Cegonha[Internet]. Brasília: Ministério da Saúde, 2011 [cited 2019 Jan 20]. Available from: http://bvsms.saude.gov.br/bvs/saudelegis/ gm/2011/prt1459_24_06_2011.html

8. Ministério da Saúde (BR). Portaria n 2048, de 04 de novembro de 2002. Aprova o Regulamento Técnico dos Sistemas Estaduais de Urgência e Emergência. Brasília: Ministério da Saúde, 2002. Available from: http://bvsms.saude.gov.br/bvs/saudelegis/gm/2002/ prt2048_05_11_2002.html

9. Michilin NS, Jensen R, Jamas MT, Pavalqueires S, Parada CMGL, et al. Analysis of obstetric care provided by the Mobile Emergency Care Service. Rev Bras Enferm. 2016;69(4):625-30. doi: 10.1590/0034- 7167.2016690408i

10. Abreu KP, Pelegrini AHW, Marques GQ, Lima MADS. [Users' perceptions of urgency and reasons for using the mobile pre-hospital care service]. Rev Gaúcha Enferm [Internet]. 2012 [cited 2019 Jan 20];33(2):146-52. Available from: http://www.scielo.br/pdf/rgenf/v33n2/21.pdf

11. Narayan B, Nelson-Piercy C. Medical problems in pregnancy. Clin Med [Internet]. 2017[cited 2019 Jan 20];17(3):251-7. Available from: http:// www.clinmed.rcpjournal.org/content/16/Suppl_6/s110.long

12. Novaes ES, Oliveira RR, Melo EC, Varela PLR, Mathias TAF. Obstetric profile of public health system users after implantation of the network mother from the state of Paraná-Brazil. Cienc Cuid Saúde. [Internet]. 2015[cited 2019 Jan 20];14(4):1436-44. Available from: http:// periodicos.uem.br/ojs/index.php/CiencCuidSaude/article/viewFile/27343/16488. 4

13. Matuszkiewicz-Rowinska J, Małyszko J, Wieliczko M. Urinary tract infections in pregnancy: old and new unresolved diagnostic and therapeutic problems. Arch Med Sci. [Internet]. 2015[cited 2019 Jan 20];11(1):67- 77. Available from: https://www.ncbi.nlm.nih.gov/pmc/ articles/PMC4379362/

14. Fossum S, Vikanes AV, Naess $\varnothing$, Vos L, Grotmol T, Halvorsen S. Hyperemesis gravidarum and longterm mortality: a populationbased cohort study. BJOG [Internet]. $2016[$ cited 2019 Jan 20];124 (7):1080-7. Available from: http://onlinelibrary.wiley.com/ doi/10.1111/1471-0528.14454/full.

15. Ye C, Ruan Y, Zou L, Li G, Li C, Chen Y, et al. The 2011 survey on Hypertensive Disorders of Pregnancy (HDP) in China: prevalence, risk factors, complications, pregnancy and perinatal outcomes. PLOS ONE[Internet]. 2014[cited 2019 Jan 20];9(6):e1001180. Available from: http:// journals.plos.org/plosone/article?id=10.1371/journal.pone.0100180

16. Ministério da Saúde (BR). Conselho Nacional de Saúde- -CNS. Resolução no 466 de 12 de dezembro de 2012. Dispõe sobre as diretrizes e normas regulamentadoras de pesquisas envolvendo seres humanos. Brasília: Ministério da Saúde, 2012.

17. Rezende J, Montenegro CAB. Obstetrícia Fundamental. 13. ed. Rio de Janeiro: Koogan, 2014. 764 p. 
18. Sociedade Brasileira de Cardiologia. 7a Diretriz Brasileira de Hipertensão Gestacional. Arq Bras Cardiol 2016;107(3Supl.3):1-83. doi: 10.5935/ abc.20160159

19. Teasdale G, Jennett B. Assessment of coma and impaired consciousness: a practical scale. Lancet. [Internet] 1974;2:81-84. doi: 10.1016/ S0140-6736(74)91639-0

20. Calegari RS, Gouveia HG, Gonçalves AC. Intercorrências clínicas e obstétricas vivenciadas por mulheres no pré-natal. Cogitare Enferm[Internet]. 2016[cited 2019 Jan 20];21(2):1-8. Availabre from: https://revistas.ufpr.br/cogitare/article/view/44604/28558

21. Monteiro MM, Moura-Sá GG, Oliveira Neto JG, Lopes KDCL, Carvalho DA, Martins MCC. Emergências obstétricas: características de casos atendidos por serviço móvel de urgência. Rev Interd [Internet] 2016;9(2):136-44, May/Jun. Available from: https://revistainterdisciplinar. uninovafapi.edu.br/index.php/revinter/article/view/948/pdf_320

22. Freitas F. Rotinas em obstetrícia. $7^{a}$ ed. Porto Alegre: Artmed, 2011, p.45.

23. Silva JG, Chavaglia S, Chavaglia R, Ruiz MT. Ocorrências obstétricas atendidas pelo serviço de atendimento móvel de urgência. Rev Enferm UFPE. 2018;12(12):3158-64. doi: 10.5205/1981-8963-v12i12a237918p3158-3164-2018

24. Pedreira M, Leal I. Terceiro trimestre de gravidez: expectativas e emoções sobre o parto. Psicol, Saúde Doenças. 2015;16(2):254-66. doi: $10.15309 / 15$ psd160210

25. Veronese AM, Oliveira DLLC, Nast K. Risco de vida e natureza do SAMU: demanda não pertinente e implicações para a Enfermagem. Rev Gaúcha Enferm[Internet]. 2012 [cited 2019 Jan 20];33(4):142-8. Available from: http://www.scielo.br/pdf/rgenf/v33n4/18.pdf

26. Félix HCR, Corrêa CC, Matias TGC, Parreira BDM, Paschoini MC, Ruiz MT. Sinais de alerta e de trabalho de parto: conhecimento entre gestantes. Rev Bras. Saude Mater Infant. 2019;19(2):335-41. doi: 10.1590/1806-93042019000200005

27. Anversa ETR, Nunes LN, Dal Pizzol TS, Bastos GAN, Qualidade do processo da assistência pré-natal: unidades básicas de saúde e unidades de Estratégia Saúde da Família em município no Sul do Brasil. Cad Saúde Pública. 2012;28(4):789-800. doi: 10.1590/ S0102-311X2012000400018.

28. Dias JMC, Lima MSM, Dantas RAN, Costa IKF, Leite JEL, Dantas DV. Profile of state prehospital mobile emergency care service. Cogitare Enferm. 2016;21(1):01-9. doi: 10.5380/ce.v21i1.42470

29. Monteiro MM, Sá GGM, Oliveira Neto JG, Lopes KDCL, Carvalho DA, Martins MCC. Emergency obstetric: case features served in mobile service urgente. Rev Interdisc. 2016;9(2):136-44. doi: 10.5205/1981-8963-v12i12a237918p3158-3164-2018

30. McDonald JA, Riskel K, Escobedo MA, Arellano DE, Cunningham TJ. Obstetric emergencies at the United States-Mexico border crossing in El Paso, Texas. Rev Panam Salud Publica [Internet]. 2015 [cited 2019 Jan 20];37(2):76-82. Av https://www.scielosp.org/article/rpsp/2015. v37n2/76-82/en/

31. Portiño MC, Novoa DG, González-Burboa A, Aguilera CL, Fernández NP, Astorga PV. Evaluación de la categorización de las urgências ginecoobstétricas en un hospital der sur de Chile. Rev Chil Obstet Ginecol. 2016;81(2):105-12. doi: 10.4067/S0717-75262016000200004

32. Farias DC, Celino SDM, Peixoto JBS, Barbosa ML, Costa GMC. Acolhimento e resolubilidade das urgências na estratégia saúde da família. Rev Bras Educ Med. 2015;39(1):79-87. doi: 10.1590/1981-52712015v39n1e00472014

33. PohImann FC, Kerber NPC, Pelzer MT, Dominguez CC, Minasi JM, Carvalho VF. Prenatal care model in the far South of Brazil. Texto Contexto Enferm. 2016;25(1):2-8. doi: 10.1590/0104-0707201600003680013 